\title{
Celebration of childbirth through dance and the demystification of the male child in the Igbo Patriarchal Society: A decisive exposition
}

\section{Christian Chima Chukwu* and Ignatius Sunday Ume}

Novena University. Department of Sociology. Ogume. Delta State. Nigeria. *Email: chukwuchidr@gmail.com.

\begin{abstract}
Celebration of childbirth, among the Igbo, is looked upon as an occasion of feasting and so every festal feature, especially good music is made available as a mark of thanksgiving to God. The birth of a new child is announced with a special kind of song called irri muo, and it is sung in celebration of the birth. Songs sung at childbirth are called umanwa, while in neighbouring communities, they are egwu omugho. Umanwa music is exclusively performed by women, and has survived until today in its original form through oral tradition. This paper, therefore, examines the celebration of childbirth through dance and the demystification of the male child in the Igbo Patriarchal Society. Among the findings, the paper acknowledges that there is always some excitement, merriment, joy and intoxication, mixed with some sparks of faith when the new entrant is added to a household. In addition, the paper recognizes that women are never fully recognized as mothers until the birth of a boy child. Disturbing as the preference is, this paper wonders and questions why women are being easily ridiculed, subjugated and divorced when and where the Y-chromosome, the sole determinant of the birth of the boy child is the exclusive preserve of the male gender. With this, the paper argues that since human personality, a prerogative and quality of every human being does not rest on gender, but on ability; the emphasis on the boy child is absolutely unnecessary because it does not add anything to ability. The paper further calls on the educated elite to enlighten their people to be aware that the dignity of the girl child is fundamentally, essentially and unquestionably equal to the dignity of the boy child. Finally, the paper concludes that, the male child has not in most cases fulfilled the long awaited expectations of being the second father in the house.
\end{abstract}

Keywords: Igbo Patriarchal Society; Inu nwunye; Egwu omugho; Demystification of the male child; Human personality.

Resumo. Celebração do parto através da dança $e$ a desmistificação do menino na Sociedade Patriarcal Igbo: uma exposição decisiva. A celebração do parto, entre os Igbo, é encarada como uma ocasião de festa e, portanto, todos os aspectos festivos, especialmente a boa música, são
Received

Sept. 10, 2019

Accepted

Feb. 21, 2020

Available on line

Apr. 22, 2020

Release

Apr. 30, 2020

Open access

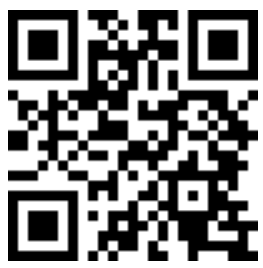

(1) $0000-0002-4290-234 \mathrm{X}$ Christian Chima Chukwu

(D) 0000-0001-8044-3351 Ignatius Sunday Ume

Rev. Bras. Gest. Amb. Sustent.

http://revista.ecogestaobrasil.net 
disponibilizados como sinal de agradecimento a Deus. O nascimento de um novo filho é anunciado com um tipo especial de música chamada irri muo, e é cantada em comemoração ao nascimento. As canções cantadas no parto são chamadas umanwa, enquanto nas comunidades vizinhas são egwu omugho. A música umanwa é executada exclusivamente por mulheres e sobreviveu até hoje em sua forma original através da tradição oral. Este artigo, portanto, examina a celebração do parto através da dança e a desmistificação do filho do sexo masculino na Sociedade Patriarcal de Igbo. Entre as descobertas, o artigo reconhece que há sempre alguma emoção, alegria, diversão e intoxicação, misturadas com algumas faíscas de fé quando o novo participante é adicionado a uma família. Além disso, o artigo reconhece que as mulheres nunca são totalmente reconhecidas como mães até o nascimento de um menino. Por mais perturbadora que seja a preferência, este artigo pergunta e questiona por que as mulheres estão sendo facilmente ridicularizadas, subjugadas e divorciadas quando e onde o cromossomo $\mathrm{Y}$, o único determinante do nascimento do menino, é a reserva exclusiva do sexo masculino. Com isso, o artigo argumenta que, do ponto de vista da personalidade humana, uma prerrogativa e qualidade de todo ser humano não se baseia em gênero, mas em habilidade; a ênfase no menino é absolutamente desnecessária porque não acrescenta nada à capacidade. 0 artigo pede ainda que a elite educada ilumine seu povo e saiba que a dignidade da menina é fundamental, essencialmente e inquestionavelmente igual à dignidade do menino. Finalmente, o artigo conclui que, na maioria dos casos, o filho do sexo masculino não atendeu às esperadas expectativas de ser o segundo pai em casa.

Palavras-chave: Sociedade Patriarcal Igbo; Inu nwunye; Egwu omugho; Desmistificação do filho do sexo masculino; Personalidade humana.

\section{Introduction}

Sex and hunger are the two great desires that dominate the being of man. Hunger compels him to look for food so that his individual survival is guaranteed. Sex, on the other hand, makes him distinguish himself as an able representative of God by embarking on the unique role of procreation. Without any doubt, one of the most precious gifts, which God has bestowed on mankind, is that which accompanies the power to procreate. With it, man is able to perpetuate his existence, in his offspring. Procreation is, and in fact, a societal phenomenon, celebrated lavishly in order to give it the beauty and grandeur it deserves.

This assertion clearly explains why the celebration of the birth of a child begins at conception. The joy of the expectant mother knows no bounds as she cheerfully sings and dances harmoniously, swerving her body mass tenderly from the right to the left, unknown to her that her songs have enchanted neigbhours. The scenario of not knowing that her melodious tunes have attracted admirers could be better explained when one juxtaposes it with an Ostrich that runs to bury its head in the sand, and believing that it had hidden itself from public glare, but unknown to it that its entire body is still visible to passers-by. Evidently, unlike the Ostrich that pretends to hide, the bulging size of the 
woman's stomach after the first trimester is incontrovertible. Undoubtedly, pregnancy is a thing of joy; it calms nerves, soothes the mind and assures one of a promising tomorrow hence, the ballad sung. The ballad, Chukwu (2015) asserts, is in honour of the expected child who, by customs and traditions, is extensively looked upon as the uniting link in the rhythm of life, guaranteeing the continuation of a blissful tomorrow from generation to generation. Observably, motherhood is a gift from God to mankind.

For those in love with humanity, Chukwu (2015) writes that childbirth is an avalanche of blessings from nature to man. Thus, much honour and admiration accompany it. Interestingly, this passion for the child is clearly, not because of what it is but for what it will eventually become. It is, therefore, in the recognition of the dynamism, dream, fortune and future of the family and humankind at large that this natural blessing manifested in the child. Wonderfully, life becomes for the parents a pleasant journey along a smooth bushy path where the dew at dawn sends cold shivers down the nerves; thus, adding a pinch of salt to humanity (Chukwu, 2015).

Elucidating further, Chukwu (2015) says when people reflect on the cherished ideals of motherhood, there comes immediately a touch of happiness, security, laughter and contentment. Evidently, the new infant re-ignites the hope for tomorrow, not necessarily because women are created with maternal instincts but because motherhood is a much sought after status in Igbo patriarchal society. This, puts in a nutshell, explains why there are always smiles of contentment and cheerfulness each time a pregnant woman is spotted walking leisurely. For Chukwu (2015), she is always as charming and interesting to admire, as any man with a protruding belly is irritating.

In the patriarchal Igbo society, it is the dream of every woman not only to get married but also to become a mother and having a child is the only means of acquiring this status (Abasili, n.d.). But in the event of the failure to become a mother, she takes all blames whether real or imagined; she becomes a social misfit, and oftentimes humiliated openly and addressed as a man (Metuh, 1999). It is only after conception and thereafter, becoming mothers do wives feel their womanhood really vindicated, authenticated and satisfied (Abasili, n.d.). However, since property inheritance (especially assets) is the exclusive right of the male child, humiliation awaits women who have only female children (Eboh, 2003). Thus, a woman with only female children suffers, to a large extent, the plight of a childless woman (Uwalaka, 2008). The mere thought of knowing that she risks losing her husband to another who will bear a son makes life unbearable for her. This explains why she is never tired of visiting traditional herbal practitioners cum diviners (Dibia), ill-equipped as they are without any scientific reproductive knowledge, to solicit for conception, and then, birth of a son. From this perspective, woman's desperation in search of progeny is understandable. In a nut shell, in most African societies and elsewhere, anyone who dies without leaving behind a child or someone close enough to remember him or pour libations for him is generally regarded as a very unfortunate person. And so, childbirth is viewed universally as one of nature's memorable happenings of great biological significance. It is imperative to acknowledge that one is not oblivious of the fact that birth marks the entrance into the world of a new stage, comprising of many actors whose total life chances are often largely determined by the circumstances of their entry. Sequel to this, experience shows that there is always some excitement, merriment, joy and intoxication, mixed with some sparks of surprise at the birth of any child.

Among the Igbo, the centrality of marriage rests on begetting children; it is a social and religious duty that makes marital vows meaningful and fulfilled. For all intents and purposes, marriage, among the Igbo, is an indispensable function mandatorily required with as little delay as possible after reaching the age of puberty. This act occupies a prime place in the culture, tradition and customs of the people as getting married looms upon the horizon of every maid and youth. The continuation of the lineage is fundamental to the Igbo people, and marriage is the natural and cultural way of guaranteeing the lineage 
immortality. Writing on the significance of marriage, Obi (1970) asserted that marriage is the lawful living together of man and woman of different families for the purpose of begetting children after some rites have been performed. A cursory look at Obi's position above implies that marriage is a mile-stone in the life of a man and a woman, which will enable them to immortalize their remembrance through their children. It is this perspective that informs Mary (1999) to contend that the begetting and training of children are the primary ends of marriage. Contributing to the discourse, Charles (2010) holds marriage is a socially approved sexual and economic relationship between two or more persons that are assumed to be permanent and include mutual rights and obligations'. This definition highlights amongst others, one fundamental aspect - the regulation of sex and childbearing, and marriage is good for reproduction.

Following this, sexual union between married couples is perceived primarily as an act for procreation, and not merely a pleasurable exercise as some authors in developed countries would argue. In other words, the idea of voluntary childlessness in which couples for various reasons wittingly abstain from having children either through the practice "coitus interruptus" during sexual intercourse, and wasting semen on the ground, or any other means, is not only abnormal, but an aberration to Igbo culture. Since marriage in Igbo patriarchal society is all about begetting children, any sexual intercourse going by the Igbo belief system, is expected, to put an end to the search for offspring. Concisely, Abasili (n.d.) writes that sexual intercourse is projected to manifest in conception, and then, birth; separation of one from the other is an anomaly. To this extent, Afigbo (2005) expresses disapproval of the use of contraceptives and practice of abortion since among the people, sexual union is not a mere sexual activity as such, but one with a very strong social and religious values fasten to it for the reason that it leads to procreation -- the creation of a new life.

In view of the fact that children occupy the central point in marriage, the father of every family requests, prior to marriage, for children every morning in his kola nut prayer for his sons, while the mother does same while venerating her personal god (chi) during annual festival. Expatiating further, Obi (1970) puts it better when he says if you ask the ordinary Igbo man why he desires to marry, the spontaneous answer will be: I want to marry in order to beget my own children, to get a family like my parents (Obi, 1970). Against this background, one can argue that one of the most precious gifts to humankind is the ability to procreate; without any doubt, people are able to perpetuate their existence, in their offspring. Thus, childbirth is viewed as one of nature's memorable happenings of great biological significance. From the foregoing, in the Igbo society which is more or less chauvinistic, it is therefore obvious that marriage and procreation are intertwined and inseparable. It is almost always presumed that readiness for marriage is readiness for procreation; to get married is an opportunity to contribute freely, through procreation, to the survival of the lineage and society at large. In addition to this, there is also the issue of social conditioning targeted at women, and which, unfortunately they have swallowed hook, line, and sinker. The social conditioning holds from childhood that women, irrespective of their other interests, will never be fulfilled unless they are married and have children.

Based on this, the Igbo people bequeath so much value on childbirth; they generally agree that childbirth brings a flood of blessings from nature to man (Chukwu, 2015). Succinctly, this concurrence finds meaning in the excitement in the birth of the child, not because of what the child is, but for what the new born child will ultimately become. It is, therefore, in the respect of this expectation that, Chukwu (2015) asserts that the dynamism, dream, fortune and future of the family and humankind at large manifests natural blessing on the child. Prior to this, Abasili (n.d.), holds that one of the most appreciated and common gestures of good-will shown to the newly married couple during marriage is prayer offered for them for the fruit of the womb: 'may God grant you many 
children', 'you shall give birth to male and female', 'in nine months we shall gather to celebrate the birth of your baby'. As a follow-up to this noble cause, life becomes for the parents, according to the Igbo cosmology, a pleasant journey along a smooth bushy path where the dew at dawn sends cold shivers down the nerves thereby adding a pinch of salt to humanity(Chukwu, 2015).

\section{Music for the celebration of childbirth}

Every childbirth celebration is looked upon as an occasion to express thanksgiving to God, feast and so every festal feature, especially good music is provided. Among the Igbo people, music makes the hearts go fonder because of the sweetness it renders to the soul. As a result, every festivity in Igboland is most often accompanied by one kind of music or the other as celebration varies from one to another. The best music is only considered well enough for the celebration in order to give it the grandeur it deserves. Generally, among them, music springs from the nature of the celebration, such as childbirth rather from outside. The birth of a child is announced with a special song called irri muo, in celebration of the birth. These special of songs are also called umanwa, while in some other Igbo communities, they are egwu omugho. Umanwa music is exclusively performed by women, and has survived until today in its original form through oral tradition.

Egwu omugho musical arts required for celebrating a new birth, and thus, the songs sung have become an integral part of community life. This explains why as soon as some words arrive that a woman has been delivered of a child, the first woman that learns of this immediately raises her voice in ululation in such a dramatic, joyful, and noisy manner as to attract every lover of good news within earshot to the source of the irri muo music. The umanwa songs are accompanied with shouts of joy. The performances involve intense musico-dramatic expressions as well as spontaneous dynamic movements and dance. The text of such songs contains prayers for the health of the new child and the mother, societal expectations of the child, thanksgiving to God for the safe delivery of the child, and prayers for the family and the community at large. Upon news of the birth, the new father buys drinks, normally palm wine to entertain his well-wishing guests. If the new-born is male, the shout would be thus:

\section{Oro ri oooooooh, Oke o! Oke o! (A male child is born).}

At the announcement of the birth of a male-child, the women sing folk-songs and invite a man who has a gun to fire it: onyi ji egbe gbaa nga, meaning: He, who has a gun, let him fire. In their understanding, a king has been born! In contrast, however, at the birth of a female baby, the chant is: Oro ri oooooooh, Omuru ikom! (A concubine is born). The women, this time, will invite a wealthy man (with much money) to come and behold a queen: Onye ji ego gbaa nga, meaning: He, who has money, let him come forth. By interpretation, suitors should come forth! Essentially, the response to the birth of the male-child pre-announces a person who has authority to live in the house and protect his family, while that of the girl-child invites rich suitors.

From the cadence of the song, 'Oke' simply means that the infant is a male child. While Nne, the direct opposite of Oke was abandoned for 'Ikom' for the new born infant girl. One of the greatest flaws in the Igbo patriarchal society is the subjugation and discrimination against women. Even as young and tender as she is, her abuse and discrimination have already being entrenched. Since there are always reasons for whatever anomaly in the society; the Igbo society is not exempted. Following this, the forebears, in their wisdom, justifies the title: ikom which literally means 'concubine', 'mistress' for the infant child for the reason that she is certainly going to be an illegitimate wife', Contextually, concubine refers to 'an illegitimate wife', which on the surface does not 
make any sense when used in announcing the birth of female child. Incidentally, no respondent or discussant was able to proffer reasons why 'concubine' is employed to announce the birth of new infant girl. However, in patronizing the ancestors, the only logical explanation is the belief that the father's affection would be keenly contested between mother and daughter - the supposed concubine.

Without mincing words, as the shout of the birth reaches the square, anyone who hears it would respond in equally loud voice, 'tisie ya ike oooo!' which means 'shout it louder'. The response is also an acceptance of the invitation to come and celebrate the beginning of new life. As is customary, people who respond to the call would immediately abandon whatever chores they are doing and head towards the home of joy. When the cocelebrants and visitors arrive, Azuonye (2007) averred that the nuclear or extended family to which the child is born would present Nzu (Kaolin chalk) or powder as the current trend is today, to them. Most people would snap off a few pieces and throw them into their mouths, and then mark their necks, faces and hands with the rest. Others would melt the chalk in water making a nice tasty cream of some sort and apply on some parts of their body. In no distant time, a small crowd gathers. Everyone in the crowd is ready for the dance party. An infant is always welcomed with a party of songs and dance, but only women tend do the dance. In the entire Igbo, every healthy woman participates including passers-by in solidarity, and also in the singing and dancing of egwu omugho, irri muo or umanwa music. Except a woman has a serious ailment or is socially ostracized sitting while this music is performed is unacceptable. Umanwa muo songs are the most popular songs sung to announce the birth of a new child and they also serve as outlets for communal bonding and solidarity among women.

The women's musical performances during omugho ceremonies feature songs that have text containing allusive/sex education passages, not obscenities. Such passages are intended to call attention to the act of procreation and the pleasures derivable from it. Azuonye (2007) also says it calls attention to the mystery of human procreation and conducts sex education in a very innocuous way. Above all, it is intended to explain procreation as well as motivate unmarried men to get married.

In sequence, the celebration songs and dance begin with: Onye nuru akwa nwa. The significance of this song lies in the fact everyone should celebrate the birth of a new entrant into the world. The song goes thus:

\section{Onye nuru akwa nwa eeeeh \\ Onye nuru akwa nwa mee ngwa ngwa \\ Obughi otu onye nwe nwa}

Whoever hears the cry of a baby eeeeh

Whoever hears the cry of a baby, hurry

A child does not belong to one person

Ororiooooooooh,

Oke o! Oke o! (Or ikom as appropriate)

Onye nuru akwa nwa eeeeh

Onye nuru akwa nwa mee ngwa ngwa

Obughi otu onye nwe nwa

Among the Igbo people, this is the most common song that emphasizes the importance of an infant in the community and the duty of every person to care and shield the infant at all times because it is defenseless. "The cry of an infant may simply be the normal cry of an infant; after all, cries are what infants do. Still, the cry may be a result of 
hunger, pain, injury or loneliness. According to Azuonye (2007), this song asks everyone who hears the cry of an infant to rush to the scene, and if the infant is hungry, to feed it, if the infant is in pain or injured, to assist in any way to soothe the infant, or if the infant is simply lonely, to provide company. Conclusively, the infant, Azuonye, asserts, does not belong only to his or her parents, but to everyone that responds appropriately to the cry.

After the party has kicked off in full swing with that song, it is promptly followed by "Onye bisa aka n'ala" - the first real song of celebration. It is a call to enjoy the blessing, with fun and energy:

$\begin{array}{ll}\text { Solo: } & \begin{array}{l}\text { Onye bisa aka n'ala } \\ \text { Biara ihe oma biaru nga ya }\end{array} \\ \text { Response: } & \text { Iya O! } \\ \text { Solo: } & \text { Everyone touch the ground with your hand } \\ & \text { Touch the good thing that has come to her home. } \\ \text { Response: } & \text { Yes O! } \\ \text { Solo: } & \text { Onye bisa aka n'ala } \\ & \text { Biara ihe oma biaru nga ya } \\ \text { Response: } & \text { Iya O! }\end{array}$

This beautiful and energetic song is sung and enjoyed by the women dancing in a circular formation; they bend over, touch the ground, rise, touch their hearts, and then raise their hands to the heavens. This song, according to Azuonye (2007), is particularly interesting and ties in neatly with the first song because the soloist asks all the women dancing to touch the ground, but instructs them to touch the good thing that has come to their homes and not necessarily to the home of the celebrating family. This is because the child belongs to each and every one of those women. The birth of that child has increased every one of them.

Afterwards, there are usually some series of songs which are very much tipped towards sex and fun and in some cases could be quite rude in their celebration of life and fun. An example of one of these songs is: Oku nkwa na-akum nkwa. This song, according to Azuonye (2007), is usually quite funny to listen to and says a lot by what it does not say.

Oku nkwa na-akum nkwa.

N'ike n'ike n'ike

Oku nkwa na-akum nkwa.

N'ike n'ike n'ike

Agadi nwoke, agadi nwanyi

N'agbara m akwukwo

N'ihe nwanchoronwu

oku nkwa na-akum nkwa

N'ike n'ike n'ike

The gong beater is beating me like a gong

With power, with power, with power

The gong beater is beating me like a gong

With power, with power, with power

Old man, old woman,

They are suing me

Because of 'Nwanchoronwu'

The gong beater is beating me like a gong

With power, with power, with power

Rev. Bras. Gest. Amb. Sustent., 2020, vol. 7, n. 15, p. 193-209. 
This song equates sexual act to a musical performance with a powerful rhythm. The beauty of this song, Azonye (2007), asserts that the woman sees herself almost like a musical instrument, being beaten by the man in such great rhythm that she responds and gets vocal in the process: groaning and moaning and keeping the neighbours awake or simply disturbing their peace - hence the lawsuit. Elucidating further, Azonye explains that Nwanchoronwu is slang for the lovemaking, and from all intents and purposes, it is a totally nonsensical slang since the nearest translation of that expression is: in search of death. Demonstrating further, Azonye (2007) takes us to another song, "Ayon Beedi". This song is equally hilarious and may be said to be appreciative of the white man invention. The song goes thus:

$\begin{array}{ll}\text { Solo: } & \text { Ayon beedi emerela anyi ihe oma } \\ \text { Chorus: } & \text { Ehe eh! } \\ \text { Solo: } & \text { Ayon beedi emerela anyi ihe oma } \\ \text { Chorus: } & \text { Ehe eh! } \\ \text { Solo: } & \text { Ayon beedi o merele any nma } \\ \text { Chorus: } & \text { Ehe eh! } \\ \text { Solo: } & \text { Isi njin, o sughariwala } \\ & \text { O buya bu okwu bekee? } \\ \text { Chorus: } & \text { O yesu! } \\ \text { Solo: } & \text { Iron bed, it has done us good } \\ \text { Chorus: } & \text { Ehe eh! } \\ \text { Solo: } & \text { Iron bed, it has done us good } \\ \text { Chorus: } & \text { Ehe eh! } \\ \text { Solo: } & \text { Iron bed, it has done us good } \\ \text { Chorus: } & \text { Ehe eh! } \\ \text { Solo: } & \text { Engine head, it is boiling and roaring } \\ & \text { Is this not English's man language? } \\ \text { Chorus: } & \text { O yes! }\end{array}$

\section{Intepretation}

Iron bed (Ayon beedi) symbolizes the turf on which the competition was played that has yielded the great result: a child. The replacement of the traditional bamboo and straw beds with the metal-framed beds by the colonial masters made copulation less stressful. The Ayon beedi song was composed in appreciation of the invention of the colonial masters. Essentially, the women are in this song celebrating the Iron Bed because copulation was more sublime on it than on the bamboo and straw beds. The description of the male organ as 'engine head' kick-starting, boiling and roaring with increased speed and power towards the end, according to Azonye (2007), praises the poetry of that moment as having the smooth intensity of English language, with an affirmative "O yes!"

In addition to the song: Oku nkwa na-akum nkwa, Chukwu Nyezuo Anyi Nwa (God gives everyone of us a child) is another prayer - like song that is regularly sung during the celebration of childbirth. The birth of a child is a momentous and wonderful event in the life of anyone. It is also something that makes a lot of demand on the time and resources of parents. The prayerfulness of the song has a story behind it:
Solo:
Chukwu, nyezuo nu anyi nwa
Chorus: eeeh eeeh
Solo: $\quad$ Chukwu, nna, nyezuo nu anyi nwa
Chorus: $\quad$ eeeh eeeh, eeeh eeeh
Solo: $\quad$ Na onye la-adughu nke oji n'aka o 


$\begin{array}{ll}\text { Chorus: } & \begin{array}{l}\text { odughu aga l'ukwu ede, } \\ \text { Agbaya hiom, agba ya hiororom. }\end{array} \\ \text { Solo: } & \text { God, give every one of us a child } \\ \text { Chorus: } & \text { eeeh eeeh } \\ \text { Solo: } & \text { God, father, give every one of us a child } \\ \text { Chorus: } & \text { eeeh eeeh, eeeh eeeh } \\ \text { Solo: } & \text { that she who has none in hand } \\ \text { Chorus: } & \text { twisting it hiom, twisting it hiororom }\end{array}$

'Hiom' and 'Hiororom' are onomatopoeic expressions referring to the sound of attempting to harvest an ill-matured cocoyam tuber. The story behind this song, according to Azuonye (2007), is that there were once two co-wives in a polygamous family. One of the wives had many children, while the other had none. The two women would plant their cocoyams and soon after, even before the tubers had time to mature, the woman with many children would be harvesting them to feed her crowd. This earned her a lot of criticism from her co-wife, who taunted her, saying, 'woman, allow your cocoyam tubers to mature, please'. The woman with many children felt that the woman's taunts were not worth dignifying with a response, instead she prayed to God to give the woman a child, and let them see if she too would not harvest ill-matured tubers to feed her child if need be.

Celebrations like these are generally recognizable among the people, although the songs performed may be different, but whenever this song rises, it is performed thoughtfully and with sensitivity to the feelings of the women among them who have no children of their own. It is performed with sincerity, for God to bless them with children too, for it is considered far better to have a child and suffer to raise it than to be childless.

It is worthy to note that all women in Igbo, particularly the newly married are entitled to irri muo music. Therefore, it is the responsibility of every Igbo woman to fulfill this obligation during appropriate ceremonies. However, a woman who intends to attract umanwa to her home must be ready to perform the customary irri muo ceremony that entails elaborate feasting and merry-making during which omugwo music would feature, but this right could be denied any absentee who is notoriously recognized for always staying away from the singing and dancing of umanwa music of her colleagues. A woman who is unable to perform this rite is not allowed to partake of the feasting and merrymaking of another omugho ceremony until she performs the ceremony.

\section{Post-natal care}

The birth of a baby into a family ushers a long period of intensive post-natal care (omugho) for the baby and mother. This period differs from community to community if not from individual to individual. The new mother is exempted from every form of work except breast feeding her baby. For the young child and the mother, the provision of adequate food during pregnancy and lactation and the provision and promotion of breastfeeding are the most essential needs. Womenfolk in the family and neighbourhood help out in preparing her food and generally keeping the home. Her food consists of hot, peppery, sumptuous soup with plenty of fish and spices like uda, utazi, nchuanwu and uziza. Hot food is believed to be good for the cleansing of the stomach. She is bathed and her stomach is massaged with hot water regularly to reduce the flab and return it to normal size.

Upon news of the birth, the new father buys drinks, normally palm wine to entertain his well-wishing guests. Provision is made for essential items necessary for postnatal care like cotton wool, spices, palm kernel cream, coconut cream- two local creams 
that are ingestible for their medicinal qualities, etc. The mother of either couple or a close female relation is sent for to assist the new mother in taking care of the baby and managing the home. For the new mother, it is a time to relax and recuperate from the stress of nine months of pregnancy and labour pains. She takes her baths, rubs ufie (cam wood - orange-like substance) lightly into skin and dons on her best clothes.

The nursing of the navel stump to heal properly, circumcision naming ceremony and ear piercing for baby girls are landmark events in this period of omugho. Some families use the fallen off navel stump to plant tree crops like coconut as a symbolic mark of the child's growth and development.

\section{The distinctiveness of the male child}

The birth of a child is widely celebrated. However, there is much jubilation than one would anticipate if the child is male. The male child instills confidence and selfdependence, and gives a sense of control as well as the feeling of esteem and generally accepted as the guardian of power. From birth the male child is accorded more recognition than the female child. In a patriarchy society, Uchendu (1997) asserted that the male child is highly valued as the best among the equals in everything even when there is no evidence to substantiate this undue accolade. He is the king and the head. He leads in every matter whether he can take decisions that would be of importance to the society or not. He is made more important than the female child. Corroborating, Chukwu (2015), the civil liberties that accrue to the male child in almost everything is socially enhancing. The prominence reserved for the male child is unimaginable because he is looked upon as a worthy representative of the father and also as one capable of surpassing his father's accomplishments (Chukwu, 2015). In continuation to this discrimination, the a patriarchal Igbo family seeks out a guardian, a sort of a godfather to groom, inspire the male child to grow up as a man, bold, audacious, and fearless and above all, motivate him to a streak of perfections, deftness, contact, courage, experiences and accomplishments associated with the guardian.

The patriarchal society rejoices when the new infant is a male. A new messiah destined by the gods to take the place of the father and continue with the family name is born, his mental state notwithstanding at birth. Writing on this, Ozumba (2005) avers that the birth of the male child brings some excitement, merriment, and joy to the new family because in him lies the father's position even after his death to continue with the family line. Likewise, there is also happiness for the mother because begetting a son has automatically deep-rooted her in her husband's heart. According to Obi (1970), the position of a wife in her husband's family remains wobbly and capricious until she begets a male child. She becomes really secured after the glorious feat. Luckily the birth of male child brings her infectious joy and completely wipes away her sorrows. At this stage, she becomes a responsible mother in her husband's extended family. Such is the dream of every married Igbo woman: to be able to bear, not only her own children but also a male child (children). Basically, the birth of the male child gives her the title of wife, prior to this time she is regarded as a wife only in anticipation. However, it is paradoxical that in Igbo society, where barrenness and a woman's inability to bear a baby boy are treated as a calamity, does not see child adoption as a viable solution to barrenness (Abasili, n.d.). Nonetheless, research has shown according to Thatcher (1999) that, apart from biologically bearing one's children, adoption is the second viable alternative of becoming parents. This option assumes a higher value having (at least) a male child is a sine qua non to be accorded respect in the patriarchal Igbo society. In such a society, it is very reasonable for childless parents to adopt a child and nurturing a child, who calls one father or mother, from very early childhood to adulthood, constitutes in a real sense parenting, 
and makes a couple a real father and mother. It is better and easier solution than divorce and polygamy.

The love of having children also manifests in the names given to them at birth. One of these is Nwabu-uwa - meaning a child is the entire world to me. The sentiment and the high-water mark of his ambitions are captured in this name which he ranks first in his desires. Besides, there are other very expressive names such as Nwabueze - a child is a king. Nwadikachi - a child is comparable to God. Nwakasi: meaning a child is priceless, most precious; Nwaka-aku, a child out-values all wealth, Since man is literally famished with the hunger for children, Nwadi-aguu, as a name captures this desirability. Nwazuo - a child has completed it. Nwaamaka - a child is very good. Nwabugo - a child brings respect. Nwagbo - a child has settled it. Painful as it is, the fate of a barren woman is very hard one indeed. Aside from being the object of conversation and ridicule and being called Mgbaliga, Nwanyi-iga (lit. the barren one) sterile monster who has her maternal organs for mere decoration, she gets the most painful telling off if an occasion for a quarrel arises (Obi, 1970). Not infrequently, a child is born to a woman after much anguish and long years of waiting. In her joy and gratitude she may name the boy child Chukwuemeka (God has been very generous towards me). On the other hand, she is now a proud mother of a male child. Her reproach among men has been-removed. The child is a practical vindication of her womanhood. As an answer to her critics, this boy child may be called Ekwutosi (ekwutozina Chukwu) cease criticizing God; or Beatokwu (Benata-okwu) (cut-short-word) meaning, "lessen now your loud-mouthed criticism".

Regrettably, the Igbo ethnic group is, in all respects, a man's world, and as a result, parents want boy children, not girl children. Corroborating this assertion, Okonkwo declares: "I will not have a son who cannot hold up his head in the gathering of the clan..." (Achebe, 1958: 30). No matter how prosperous a male child is, if he is unable to rule his household, he is a weak male child. In the bid to groom a male child to embrace his responsibilities, masculine stories of violence and bloodshed to them in order to harden them and set up them for the potential functions of being defenders, and leaders. The joy of seeing one's male child beginning to shed feminine tendencies gladdens the hearts of parents in a patriarchal society and he knew it was due to Ikemefuna. He wants his boy child, Nwoye, to grow into a tough young man capable of ruling his father's household. To this extent, Chukwu (2015) asserts that fathers are happy whenever they take notice of their male children grumbling about women.

Observing the preparation of the male child for tomorrow, Ogbunugo Anyiam cited in Chukwu (2015) remarks that "to leave the child to fend for himself or to let him live and grow with the dangers of his father's light handed upbringing is akin to undue pampering which is like spelling disaster at the commencement of the journey of life for the youngster". Corroborating this perception, Chimaroke (2006) argues that no one doubted the utility value of guardian, whose challenge is not only to bring up the male child, but go to sleep in the wake of the exhibition of the prowess as the kid is under compulsion to bring to play his own version of the journey of life. If we continue to look at the preparation of the boy child from the foregoing perspective, we have to further accept the slightly developed theory of Idoma nma-agaba-idu - the young lion-which on learning the whole tricks of the supremely powerful master took over kingdoms and territories which the guardian and tutor never dared, even if the great forerunner was hindered by the finesse of diplomacy and respect for tradition.

Going by the patriarchal culture, Achebe (1958) cited in Chukwu (2015) paradoxically depicts Okonkwo as efulefu in spite of his accomplishments because of the cold tremble that runs through him each time he remembers that he has no 'male child' to perform those rare traditional rites accorded great men of his stature at their demise. The fear of not been admitted in the prestigious status of ancestor (Ichie) after his death accounts for Okonkwo's lamentation (Abasili, n.d.). Need one blame Okonkwo when 
viewed against the fact that his name (Aham) and all he ever represented would be lost? Igbo names like Ikemefuna (my lineage will not disappear), Ahamefuna (my name shall not be lost reveal the strong yearning for heir and progeny based immortality lurking in the heart of every Igbo man (Abasili, 2004). However, it is incongruous that Okonkwo did not recognise his child, Nwoye as a male child. Admittedly, for an Igbo man to die childless or without a male child is a calamity. In Igbo patriarchal society, "to die childless is tantamount to a descent into oblivion, to be forgotten by both the living and the dead. This is because such a person has left no heir to pour libation for him (Abasili, 2004). But in Okonkwo's situation, there stands Nwoye, a male child. There is obviously a contradiction, and the incongruity in this situation is indescribable. Admittedly, for an Igbo man to die childless or without a male child is a calamity. In Igbo society, "to die childless is tantamount to a descent into oblivion, to be forgotten by both the living and the dead. This is because such a person has left no heir to pour libation for him (Abasili, 2004). Apart from attempting answering the following questions emanating here from: "what is the explanation for the cold shudder that runs through him at the terrible prospect, like the prospect of annihilation? Why did he abandon Nwoye and decided to see himself and his father's spirit crowding round their ancestral shrine waiting in vain for worship and sacrifice and finding nothing but ashes of bygone days? How can Okonkwo contradict the Igbo patriarchal society that values male children, and yet does not recognise Nwoye as such? The study hopes to expatiate further by attempting questions such as: Does Okonkwo believe that his male child, Nwoye, as his heir cannot pour libation in his honour? At this juncture, the question that comes to mind is: Has the Igbo patriarchal society soft-peddled on patriarchy? The other question is to what extent has Okonkwo's imperfection corrected the over emphasis on male children?

\section{The futility of the search for male children}

In his disappointment, Okonkwo, the protagonist in the novel, Things Fall Apart, confesses that his child, Nwoye, whom he had devoted so much time mentoring was worth nothing. Having been faithful to the gods of his ancestors, he cried in his heart why he, Okonkwo, of all people, could be cursed with such a male child? For abandoning the gods of his ancestors and going about with a lot of effeminate men chucking like old hens was the very depth of abomination Nwoye has roped himself in (Achebe, 1958:139). This lamentation captures Okonkwo's frustration as he walks alone vainly around his ancestral shrines waiting for worship and sacrifice and finding nothing, but the ashes of bygone days because his so-called male child, Nwoye, has deserted him at this ominous time is heart breaking. The pitiable situation of Okonkwo explains vividly the kind of cold shudder that normally runs through any Igbo at the terrible prospect of having no male child to perform those rare traditional rites and rituals reserved for family's ancestors to ginger their spirits to protect and influence events in the lives of the living.

In all this, Iwe (1985:168) asserts that the dignity of the female child is fundamentally, essentially and unquestionably equal to the ingenuity of the boy child. Elucidating further, Chukwu (2015) declares that the resourcefulness of the female child is based on human personality, which is the prerogative and quality of every human being, male or female, thus, the truth of this testimonial remains incontrovertible in spite of sex differences, for individual's dignity hinges not on sex but on character; and quality as such has no sex (Iwe, 1985:168). Okonkwo's reversal to announce the dexterity, reasonableness, and resourcefulness of his female child, Ezinma is all interesting, and soul reliving. Aligning with Iwe, though unknowingly, Brien et al. (1995) cited some sections of the laws of Manu which consist of 2,685 verses to reposition the place of the female child thus: 
Women must be honored and adorned by their fathers, brothers, husbands and brothers-in law who desire great good fortune. Where women are honored, there the gods rejoice; where, however, they are not honored, there all sacred rights prove fruitless. Where the female relations live in grief - that family soon perished completed where, however, they do not suffer from any grievance - that family always prospers... Bet father protects her in childhood, her husband protects her in youth, her sons protect her in old age - a woman does not deserve independence. The father who does not give away his daughter in marriage at the proper time is censurable; censurable is the husband who does not approach his wife in due season; and after the husband is dead, the son is censurable who does not protect his mother. Even against the slighter provocations should women be particularly guarded, for unguarded they would bring grief to both the families. Regard this as the highest dharma of all four classes: Husbands, though weak, must strive to protect their wives. The husband should engage has wife in the collection and expenditure of wealth, in cleanliness, in religious rites, in cooking food for the family, and in looking after the necessities of the household...

Critically viewing the injustice meted out to the female child in the patriarchal societies, Captain Thomas Sankara, erstwhile Burkinabe President in one of his numerous motivational speeches (Sankara, 1986) admonishes women to remain resilient in improving themselves in spite of all encumbrances. According to him, "women should not rely on men and should not expect condescension from them. The development and the liberation of women as a whole will not come about as an act of charity. It will depend on their will and their determination to struggle and, therefore, their grasp of the social contradictions that oppose women...'.

\section{Patriarchal societies and the devaluation of the female child}

As in all patriarchal societies, no guardian is sought for the female child because the Igbo society does not recognize the essence to the family since her family name will change after marriage, thus providing her with a guardian to mentor her is an aberration. At birth, a sign of disappointment, grief, hopelessness and ache envelope the entire household. Parents want male children, not female children. Even though her marriage often times brings immense wealth, her dismissal at birth obviously mirrors her devaluation as a gift to the family (Chukwu, 2015). The mind-set towards the female child remains old-fashioned, poor, treacherous and completely distasteful and harmful to the female psyche. Writing on some relic and rustic prescription that go contrary to the fundamental human rights of the females in the Igbo traditional society, Achufusi (1994) captures this dilemma in the following words:

The most pathetic thing about these women is their ineffectiveness as human beings, incapability to correct or admonish their husbands despite their knowledge of the inadequacies in the men's lives they are all aware of the superficiality, vanity, avarice, emptiness and extreme flamboyance of the kind of life their husbands lead and into which they (the wives) have been pulled. They all appear helpless, unable to break away and start a more purposeful life for themselves or make effort to bring sanity and reality into the lives of their husbands (Achufusi, 1994:162).

The yearning of Okonkwo, in the text, Things Fall Apart, that Ezinma, his much loved child, were a male child clearly reveals where his heart lies. As a researcher, this habituated love for Ezinma has shown the biases the patriarchal society has against the female child. Among the Igbo people, little is said about the standing of female children in the community apart from that, their mother is expected to properly bring them for

Rev. Bras. Gest. Amb. Sustent., 2020, vol. 7, n. 15, p. 193-209. 
marriage, and trained them to be submissive and obedient to their husbands. This explains the essence of the mother's parting word of advice whispered into her daughter's ear:

You are going to your house. You must be respectful .You must be careful. You must be fruitful; bear many sons for husband. Under no circumstances must you disobey your husband.

Accepting the foregoing, Jean Jacques Rousseau (1975:333) concurs that:

What is most wanted in a woman is gentleness; formed to obey a creature as imperfect as man, a creature often vicious and always faulty, she should early learn to submit to injustice and to suffer the wrongs inflicted on her by her husband without complaint.

Commenting on this unholy status foisted on the female child, Wollstonecraft $(1792,1975: 34)$ ridicules the female child for being created to be a man's play thing, and his clatter, and must tinkle in his ears whenever he decides. While examining the inexcusable plight of the female child in his society, Fu Hsuan, the third century Chinese scholar writes:

Bitter indeed it is to be born a woman, it is difficult to imagine anything so low. Boys can stand openly at the front gate; they are treated like gods as soon as they are born ... But a girl is reared without joy or love. And no one in her family really cares for her. Grown up, she has to hide in the inner rooms and cover her head; be afraid to look others in the face. And no one sheds a tear when she is married off... (Quoted from Nwagbara, 2005).

Corroborating this assertion, Rollin (1954:91-92) notes that, the dissimilarity between the happiness at the birth of a male child and the sadness at that of a female child is conveyed out in this poem concerning an imperial family:

A son is born. He is placed upon a bed, and clothed in brilliant stuffs. They give him a semi-sceptre. His cries are frequent. They clothe the lower part of his body with red cloth. The master, the chief sovereign, is born, and to him they give the empire.

But for the female child,

A daughter is born: They place her on the ground; they wrap her in common cloths. They place tile near to her. There is not in her either good or evil. Let her learn how to prepare the wine and cook the food. Above all she should exert herself not to be a charge on her parents to which the female children (Rollin, 1954:91-92).

If a newly born princess found no greater welcome, what is the fate of other female children born into ordinary homes? The broadcast that the new baby is a female creates huge embarrassment, because mothers are supposed to bring forth male children. Unfortunately, the few and far between mention of the female child in gathering is a clear indication of the limited value the patriarchal Igbo placed on her gender. Besides, the mentioning of wives purely as the bearers of children can also be taken as a statement that female children are actually nothing more than tools of reproduction. The rejection of the female child and her subsequent subjugation is not as a result of commonness, but most likely, because the Igbo still cling to the fact that the female child is inferior because she is groomed to become soft, subservient, weak and gentle (Chukwu, 2006). Corroborating this injustice against the girl child, it is observed that maternal care is even denied her as she is 
weaned as quickly as possible to pave way for her mother to speedily have another baby, the desired male child regarded as the solidifier of marriages.

\section{Conclusion and recommendations}

The thrust of this paper was to examine the celebration of childbirth through dance and the demystification of the male child in the Igbo patriarchal society: a decisive exposition. The paper concludes that the Igbo people are not yet sufficiently aware of the extent to which they have displaced, dislodged, disoriented, and marginalized the woman through her inordinate quest for the boy child. Consequent upon this, the surest way out of this misconception is the re-orientation of the Igbo ethnic group. Therefore, to ensure a saner, sober and healthier Igbo society, the girl child should be accorded respect and by so doing, the Igbo society would become more humane, tension-free, peaceful, creative and dynamic and more productive. In addition, there is no gainsaying the fact that, the surest way out of the undue emphasis on the boy child is the girl child empowerment through critical education, access to credit facilities and enlightenment in order for women to acquire intellectual mind power to be free from this servitude.

Based on the findings of this study, this paper upholds that, there is need for a sane revaluation of our present day cultural patterns. Against this backdrop, the paper makes the following recommendations:

1. The dignity of the girl child (woman) is based on human personality, which is the prerogative and quality of every human being, male or female (Iwe, 1985: 168). Since human personality does not rest on sex, but on resourcefulness, the ingenuity of the girl child is same as that of the boy child, therefore, the Igbo ethnic group should halt the devaluation of the girl child. Agreeing, Lips (1991: 20) have shown that the most positively valued masculine traits have to do with activity and competence.

2. The high rate of divorce in which women are being subjected to in the Igbo ethnic group for not begetting male children is worrisome because the Ychromosome, the sole determinant of the male child, is the exclusive preserve of the man. Thus, all abuses and divorce suits against women should be dropped because the Y-chromosome is the exclusive preserve of the man.

3. People should be encouraged to be androgynous, that is, capable of expressing the full range of human emotions and roles possibilities, without being restricted by gender stereotypes. This is to ensure that sex roles which are learned in the course of socialization process and also reinforced in schools, in peer groups, in the mass media and in many other agencies do not become the basic patterns of behavior expected of the sexes because all human beings are born free and equal in dignity and rights. They are endowed with reason and conscience and should be seen as such.

4. In addition, women's organizations should embark on enlightenment programmes to assist women to understand the $\mathrm{A}, \mathrm{B}$, and $\mathrm{C}$ of the reproduction processes leading to the birth of a male child so as to remove those shackles of old times which are symptomatic of the mental aberration and prejudice of former times.

5. Apart from the above, since education plays a vital role in the favourable attitude of the sexes towards each other, there is need for the government and religious leaders to make conditions conducive for the girl child to be educated if possible, at no cost. Developing the capabilities of the female children is an important investment because their population accounts for more than half of the world. 
6. Furthermore, education will raise the consciousness of the women and equip them with the tools for wisely repudiating the negative overbearing tendencies of the men. To do this successfully, women must bear in mind the biblical counsel that "Every wise woman buildeth her house but the foolish plucketh it down with her hands" (Proverbs 14:1). God has made the man as the head for administrative purposes and not to lord it over her and use her as a mere object of pleasure or menial service. This the men must know as well.

7. The enabling environment should be created to enable the women to aspire to any height without reneging on the sacred duties of wifehood and motherhood. All atavistic and anachronistic limitations of the past must be bade farewell to and so must we do to the cantankerous, disorderly assertiveness of women as seen in the pervasion of all things in our time. Sanity must rule the hearts of men and women as we continue to meaningful dialogue to affect a just social order.

\section{Conflicts of interest}

Authors declare that they have no conflict of interests.

\section{References}

Abasili, A. I. Seeing Tamar through the orism of an African woman: A contextual reading of Genesis 38. Leuven: Biblical Studies Department, K.U., n.d.

Achebe, C. Things fall apart. London: Heinemann Educational Books, 1958.

Achebe, C. No longer at ease. London: Heinemann Educational Books, 1960.

Achufusi, G. I. Female individuality and assertiveness in the novels of Ifeoma Okoye. In: Enugu, H. C. (Ed.). Feminism in African literature. New Generation Books, 1994.

Afigbo, A. E. Women in Nigerian History. In: Ijere, M. O. (Ed.). Women in Nigerian Economy. Enugu: Acena Publishers, 1990.

Afigbo, A. Religion and economic enterprise in traditional Igbo Society. In: Falola, T. (Ed.). Igbo history and society: The essays of Adiele Afigbo. New Jersey: African World Press, 2005.

Amadiume, I. Daughters, female husbands: Gender and sex in an African Society. London: Zed Press, 1987.

Chukwu, C. C. Socio-cultural practices as obstacles to women empowerment in Nigeria: A case of Bekwarra, Ogoja and Yala Local Government Areas of Cross River State. Calabar: University of Calabar, 2006. (M. Sc. thesis).

Chukwu, C. C. Sociological evaluation of the inordinate quest for the birth of the boy child amongst couples in the Igbo Ethnic Group of Southeast, Nigeria: A critical overview. International Journal of Humanities and Social Studies, v. 1, no. 1, 2015.

Eboh, B. O. Feminism and African cultural heritage. Journal of Inculturation Theology, v. 5, no. 2, p. 123-140, 2003.

Ekejiuba, F. The place of women in Igbo Society. Proceeding of the Ahiajioku Lecture Colloquium 1990, Owerri, Nigeria, 2003.

Ikonne, C. Woman as a road block to herself actualization. In: Nigeria and the Millennium Development Goals. Lagos: Fulbright Alumni, 2008.

Iwe, N. S. S. Christianity, culture and colonialism in Africa. Port Harcourt: University Press, 1985. 
Mair, L. African marriage and social change. London: Frank Cass, 1969.

Mary, A. The fifty steps to happy marriage. Owerri: Assumpta Press, 1999.

Metuh, E. I. Comparative studies of African religions. Enugu: Snaap, 1999.

Njoku, E. N. Igbo political culture. Illinois: North-Western University Press, 1974.

Azuonye, N. Egwu Nwa: Songs celebrating childbirth. Sentinel Literary Quarterly, v. 1, no. 1, $2007 . \quad$ Available from: $<$ http://www.sentinelpoetry.org.uk/SentinelLiteraryQuarterly/html/11/nnorom_azuonye.htm>. Accessed on: Apr. 22, 2019.

Nwosu. C. J. The girl child, still run your race. In: Iwara, A. U. (Ed.). Nigeria and the Millennium Development Goals. Lagos: Fulbright Alumni Association of Nigeria, 2008.

Obi, C. A. Marriage among the Igbo of Nigeria. Rome: Pontifical Urban University, 1970. (Thesis).

Obuna, E. African priests and celibacy. Ibadan: Ambassador Books, 1986.

Okorie, I. The history of the Igbos and the chronology of events. Enugu: Cecta Publishers, 1983.

Payette-Bucci, D. Voluntary childlessness. Direction, v. 17, no. 2, p. 26-41, 1988. Available from: <https://directionjournal.org/17/2/voluntary-childlessness.html>. Accessed on: Apr. 22, 2019.

Rollin, C. Social thought: From Harmmurabi to Comte. New York: The Dryden Press, 1954.

Uchem, R. N. Overcoming women's subordination: An Igbo African and Christian Perspective. Enugu: Snapp, 2001.

Uchendu, V. C. The Igbo of Southeastern Nigeria. New York: Holt, Rinehart and Winston, 1965.

Ugum, N. S. The agony of a woman. Jos: Verdem Publishers, 2003.

Uwalaka, E. C. Towards sustainable happy marriage: A functional approach. Owerri: Danstaring, 2008.

License information: This is an open-access article distributed under the terms of the Creative Commons Attribution License, which permits unrestricted use, distribution, and reproduction in any medium, provided the original work is properly cited. 